\title{
Effect of Mulching and Methods of Irrigation on Okra (Hibiscus esculentus L. Moench)
}

\author{
Vinita Parte $^{1 *}$, Pratibha Dagore ${ }^{2}$, Anjana Kujur ${ }^{2}$ and Urvashi Markam ${ }^{2}$ \\ ${ }^{1}$ Department of Agronomy, College of Agriculture, Ganjbasoda, Vidisha, \\ JNKVV, Jabalpur, MP, India \\ ${ }^{2}$ RVSKVV, Gwalior, MP, India \\ *Corresponding author
}

\begin{tabular}{l} 
K e y w o r d s \\
$\begin{array}{l}\text { Irrigation, } \\
\text { Mulching, Water } \\
\text { management, Soil } \\
\text { moisture }\end{array}$ \\
\hline Article Info \\
$\begin{array}{l}\text { Accepted: } \\
\text { 08 January } 2020 \\
\text { Available Online: } \\
\text { 10 February } 2020\end{array}$ \\
\hline
\end{tabular}

A B S T R A C T

Okra (Hibiscus esculentus L. Moench) or Lady's finger is one of the important vegetables grown throughout the tropics and subtropics. It is one of the most important vegetable grown commercially almost during the year in India. Irrigation scheduling is considered as a vital component of water management to produce higher irrigation efficiency under any irrigation system, as excessive or sub-optimum irrigation both have detrimental effects on productivity parameters of okra (Aiyelaagbe and Ogbonnaya, 1996). Mulching is effective in reducing evaporation, conserving soil moisture and has been known to modify the hydrothermal regime of soil (Bhagat and Acharya, 1988). The result of method of irrigation is found to be non significant due to continuous rainfall. Hence, there are no differences among the methods of irrigation. Mulching with plastic sheet in okra var. VRO-6 proved the best mulch practice which produced superior growth and yield attributing characters

\section{Introduction}

Okra (Hibiscus esculentus L. Moench) or Lady's finger is one of the important vegetables grown throughout the tropics and subtropics. It is one of the most important vegetable grown commercially almost during the year in India. Green fruits are cooked curry and soup. High iodine content of fruit help control goiter while leafs is used to inflammation and dysentery. The fruit also help in cases of renal colic, leucorrhoea and general weakness. It has yet multiple uses; the dry seed contains $13-22 \%$ good edible oil and $20-24 \%$ protein. The crushed seed is fed to cattle for milk production and the fibre is 
utilized in jute, textile and paper industry. Mehta (1959) reported that okra leaves are used in turkey for preparation of medicament while ripe seeds powder sometimes used as a substitute of coffee and soups. Mucilaginous material present in okra fruit is used for preparation of ice-cream is glycoprotein. The nutritional value of $100 \mathrm{~g}$ of edible portion of okra contains $1.9 \mathrm{~g}$ protein, $0.2 \mathrm{~g}$ fat, $6.4 \mathrm{~g}$ carbohydrate, $0.7 \mathrm{~g}$ minerals and $1.2 \mathrm{~g}$ fiber (Gopalan et al., 1989).

India is the leading country in okra production having an area of 4.32 lakh, production 45.28 lakh and productivity $10.5 \mathrm{mt} / \mathrm{ha}(\mathrm{FAO}$, 2009). Irrigation scheduling is considered as a vital component of water management to produce higher irrigation efficiency under any irrigation system, as excessive or suboptimum irrigation both have detrimental effects on productivity parameters of okra (Aiyelaagbe and Ogbonnaya, 1996). Moreover, scheduling irrigation is influenced by many complex factors such as soil, crop, environment, water supply and cultivation practices. Thus, it is essential to develop an efficient irrigation scheduling under prevailing local conditions. Various methods based on estimated crop evapo-transpiration rate (Jaikumaran and Nandini, 2001), ratio of irrigation water to cumulative pan evaporation (Aiyelaagbe and Ogbonnaya, 1996 and Batra et al., 2000), open pan evaporation rate (Singh, 1987 and Manjunath et al., 1994) and soil moisture depletion (Home et al., 2000) are widely used for scheduling irrigation in okra.

Mulching is effective in reducing evaporation, conserving soil moisture and has been known to modify the hydrothermal regime of soil (Bhagat and Acharya, 1988). Walter (1988) reported that the bad effects of water deficit could be overcome by irrigation or adopting in-situ moisture conservation techniques, such as use of mulches. Mulching has also been identified by many workers as a method to provide a favourable soil environment by minimizing crusting at the soil surface and keep it stable (Mehta and Prihar, 1973). Influence of mulching for tomato production has been reported by many researchers (Hooda et al., 1999 and Monks et al., 1997).

Several studies reported mulch to conserve soil moisture and improve crop yield (Singh and Gangwar, 1972; Singh et al., 1976). The assumption driving this experiment was that although crop plants vary in terms of their water requirements for growth and development, such water requirements however can be met by supplying water corresponding to amounts evaporated from the adjacent land surfaces. We tested this assumption by applying irrigation water at three levels of evaporation. The present study was undertaken with following objectives that includes, to study the effect of mulching on yield attributes and yield of okra. To find out the effect of method of irrigation on yield attributes and yield of okra. And also to determine the interaction effect between mulching and methods of irrigation on okra.

\section{Materials and Methods}

A field experiment was during the kharif season of 2012 under the edaphic and climatic condition of Gwalior (M.P.). Geographically, Gwalior is situated at the latitude of 260 13' North and longitude 760 14' east with an altitude of 211.52 meters above mean sea level. The experimental soil is sandy clay loam in texture (By Bouyoucos hydrometer method as described by Bouyoucos (1951)., with pH 7.82, EC $0.36 \mathrm{dSm}^{-1}$, Organic carbon $0.42 \%$ (Rapid Titration method proposed by Walkeley and Black's (1934) with available $\mathrm{N}$ (182.8 $\mathrm{kg} \mathrm{ha}^{-1}$ ) ( Alkaline permanganate method (Subbiah and Asija, 1956), P (13.6 kg ha-1) (Olsen's method, Olsen et al., 1954) and $\mathrm{K}$ (216 kg ha-1) (Flame Photometer) 
(Jackson, 1973). The experiment was laid out in split plot design with 4 replications. Treatments number is 12 with (combination of 3 methods of irrigation and 4 methods of mulching). Three methods of irrigation $\mathrm{M}_{1}=$ check basin, $\mathrm{M}_{2}=$ Drip irrigation, $\mathrm{M}_{3}=$ Border strip considered as main plot treatments and the subplot consists MS=Mulching with wheat straw, MG=Mulching with Grasses, $\mathrm{MP}=$ Mulching with plastic sheet, $\mathrm{MN}=\mathrm{No}$ mulch. Total number of plot is 48. Gross plot size is $5.0 \mathrm{~m} \mathrm{x} 3.6 \mathrm{~m} \mathrm{~m}$.Net plot size is $4.4 \mathrm{~m}$ $\mathrm{x} 3.0 \mathrm{~m}$. Replication border is $1.0 \mathrm{~m}$. Distance between rows is $60 \mathrm{~cm}$. Sowing was done at the rate of $15 \mathrm{~kg} / \mathrm{ha}$ on 05 July 2012 and all other cultivation practices were adopted as per recommendations. Plant height, Number of branches per plant, Dry weight per plant are measured at 30,60 DAS and harvest stage and Number of pod per plant, Length of pod (cm) at harvest stage. Post harvest studies include Number of seeds per pod, Test weight (1000 seeds weight g), Yield per plant (g) and Yield per plot $(\mathrm{g})$. Seed Yield $(\mathrm{kg} / \mathrm{ha})$ is calculated from the recorded data of seed yield per plot, seed yield was computed per hectare by multiplying the yield per plot by conversion factor.

\section{Results and Discussion}

\section{Plant height (cm)}

The method of irrigation and mulching did not show any significant interaction effect at 30, 60 DAS and harvest stage of crop. The result of method of irrigation is found to be non significant due to the continuous rainfall. The effects of mulching were significant at 30 to 60 DAS and at crop harvest. At 30 DAS, significantly taller plants (about $40.12 \mathrm{~cm}$ ) were recorded with plastic mulching than the other mulching method. Plant height of mulching with plastic was nearly at par with grasses and wheat straw mulch. At 60 DAS, significantly taller plants (about $91.56 \mathrm{~cm}$ ) were recorded with plastic mulch than the other mulching method. Plant height of mulching with plastic was nearly at par with grasses and wheat straw mulch. Similarly at harvest stage, significantly taller plants (about $106.05 \mathrm{~cm}$ ) were recorded with mulching with plastic than the other mulching method. Plant height of mulching with plastic was nearly at par with grasses and wheat straw mulch (Table 1).

Mulching of plastic sheet resulted in significantly tallest plants over rest of the all mulching practices. This was due to the fact that plastic mulches absorb comparatively large amounts of the incoming radiation and transmit a considerable part of it to the soil. The surface energy balance of plastic mulch and its influence on the crop environment are determined by the optical properties of the plastic (Ham et al., 1993). Reduced evaporation, which is a factor contributing to cooling, and higher microbial activity under plastic mulch were reported as factors adding to soil temperature (AbdelHafeez and AbuGoukh, 1984; Tarara, 2000; Sanders, 2002).

\section{Number of branches per plant}

The result of method of irrigation is found to be non significant due to the continuous rainfall. At 30 DAS, Mulching with plastic recorded the maximum number of branches (2.24/plant), which was at par with wheat straw mulching (2.07/plant). At 60 DAS, significantly maximum number of branches (5.80/plant) was recorded with plastic mulch than the other mulching method and it was followed by grasses and wheat straw mulch. At harvest stage, Mulching with plastic recorded the maximum number of branches (6.55/plant), which was at par with wheat straw mulching (6.30/plant) (table 2). Mulching of plastic sheet resulted in significantly maximum number branches per plant over rest of the all mulching practices. 
This was due to the fact that plastic mulches absorb comparatively large amounts of the incoming radiation and transmit a considerable part of it to the soil.

The surface energy balance of plastic mulch and its influence on the crop environment are determined by the optical properties of the plastic (Ham et al., 1993). Reduced evaporation, which is a factor contributing to cooling, and higher microbial activity under plastic mulch were reported as factors adding to soil temperature (AbdelHafeez and AbuGoukh, 1984; Tarara, 2000; Sanders, 2002).

\section{Dry weight per plant (g)}

At 30 and 60 DAS, significant differences among the mulching were observed in respect to the dry weight per plant. Mulching with plastic sheet resulted in significantly maximum dry weight per plant (3.12), which was at par with grass and wheat straw mulching. At harvest stage, significantly maximum dry weight per plant (21.63) was recorded with plastic mulch than the other mulching method and it was followed by grasses and wheat straw mulch (table 3 ). The consistent high temperature under plastic mulch is due to the green house effect that traps the little radiant energy and penetrates into the soil. Less moisture depletion under the mulches was a result of prevention of contact between the soil and dry air, which reduced water loss into the atmosphere through evaporation.

Table.1 Plant height at successive crop growth stages as influenced by mulching and methods of irrigation on okra

\begin{tabular}{|c|c|c|c|}
\hline \multirow[t]{2}{*}{ Treatments } & \multicolumn{3}{|c|}{ Plant height $(\mathrm{cm})$ at } \\
\hline & 30 DAS & 60 DAS & Harvest \\
\hline \multicolumn{4}{|l|}{ Methods of Irrigation (M) } \\
\hline $\mathrm{M}_{1}($ Check basin $)$ & 37.77 & 88.75 & 100.44 \\
\hline $\mathbf{M}_{2}$ (Drip irrigation) & 37.79 & 88.72 & 100.86 \\
\hline $\mathbf{M}_{3}$ (Border strip) & 37.22 & 88.51 & 100.57 \\
\hline $\mathbf{S E}(\mathbf{m}) \pm$ & 0.584 & 1.401 & 1.029 \\
\hline CD at $5 \%$ & NS & NS & NS \\
\hline \multicolumn{4}{|l|}{ Mulching (MC) } \\
\hline $\begin{array}{l}\text { MS (Mulching with wheat wheat } \\
\text { straw) }\end{array}$ & 38.67 & 91.25 & 102.46 \\
\hline MG (Mulching with grasses) & 37.62 & 90.42 & 100.95 \\
\hline MP (Mulching with plastic sheet) & 40.12 & 91.56 & 106.05 \\
\hline MN (No mulch) & 33.97 & 81.41 & 93.02 \\
\hline $\mathbf{S E}(\mathbf{m}) \pm$ & 1.029 & 0.957 & 2.162 \\
\hline CD at $5 \%$ & 2.986 & 2.779 & 6.274 \\
\hline
\end{tabular}


Table.2 Number of branches per plant at successive crop growth stages as influenced by mulching and methods of irrigation on okra

\begin{tabular}{|l|l|l|l|}
\hline \multirow{2}{*}{ Treatments } & \multicolumn{3}{l}{ Number of branches per plant at } \\
\cline { 3 - 4 } & 30 DAS & 60 DAS & Harvest \\
\hline Methods of Irrigation (M) & & & \\
\hline$M_{1}$ (Check basin) & 1.76 & 4.74 & 5.64 \\
\hline$M_{2}$ (Drip irrigation) & 1.86 & 4.83 & 5.89 \\
\hline$M_{3}$ (Border strip) & 1.68 & 4.45 & 5.49 \\
\hline SE(m) \pm & $\mathbf{0 . 0 6 5}$ & $\mathbf{0 . 0 4 6}$ & $\mathbf{0 . 1 2 9}$ \\
\hline CD at 5\% & NS & NS & NS \\
\hline Mulching (MC) & & & \\
\hline MS (Mulching with wheat straw) & 2.07 & 5.35 & 6.30 \\
\hline MG (Mulching with grasses) & 1.89 & 5.11 & 6.18 \\
\hline MP (Mulching with plastic sheet) & 2.24 & 5.80 & 6.55 \\
\hline MN (No mulch) & 0.86 & 2.44 & 3.67 \\
\hline SE(m) \pm & $\mathbf{0 . 0 9 9}$ & $\mathbf{0 . 0 7 6}$ & $\mathbf{0 . 1 1 8}$ \\
\hline CD at 5\% & $\mathbf{0 . 2 8 6}$ & $\mathbf{0 . 2 2 1}$ & $\mathbf{0 . 3 4 4}$ \\
\hline
\end{tabular}

Table.3 Dry weight per plant (g) at successive crop growth stages as influenced by mulching and methods of irrigation on okra

\begin{tabular}{|c|c|c|c|}
\hline \multirow[t]{2}{*}{ Treatments } & \multicolumn{3}{|c|}{ Dry weight per plant (g) at } \\
\hline & 30 DAS & 60 DAS & Harvest \\
\hline \multicolumn{4}{|l|}{ Methods of Irrigation (M) } \\
\hline$M_{1}($ Check basin $)$ & 2.98 & 12.99 & 21.35 \\
\hline $\mathbf{M}_{2}$ (Drip irrigation) & 2.98 & 13.00 & 21.61 \\
\hline$M_{3}$ (Border strip) & 2.97 & 12.98 & 21.09 \\
\hline $\mathrm{SE}(\mathbf{m}) \pm$ & 0.064 & 0.165 & 0.036 \\
\hline CD at $5 \%$ & NS & NS & NS \\
\hline \multicolumn{4}{|l|}{ Mulching (MC) } \\
\hline MS (Mulching with wheat straw) & 3.08 & 13.05 & 21.43 \\
\hline MG (Mulching with grasses) & 3.05 & 13.04 & 21.41 \\
\hline MP (Mulching with plastic sheet) & 3.12 & 13.10 & 21.63 \\
\hline MN (No mulch) & 2.64 & 12.77 & 20.93 \\
\hline $\mathrm{SE}(\mathrm{m}) \pm$ & 0.075 & 0.139 & 0.047 \\
\hline CD at $5 \%$ & 0.219 & 0.404 & 0.137 \\
\hline
\end{tabular}


Table.4 Number of pod per plant and length of pod $(\mathrm{cm})$ at harvest stages as influenced by mulching and methods of irrigation on okra

\begin{tabular}{|l|l|l|}
\hline Treatments & $\begin{array}{l}\text { Number of pod } \\
\text { per plant }\end{array}$ & $\begin{array}{l}\text { Length of pod } \\
\text { (cm) }\end{array}$ \\
\hline Methods of Irrigation (M) & 6.62 & 8.59 \\
\hline$M_{1}$ (Check basin) & 6.86 & 8.62 \\
\hline$M_{2}$ (Drip irrigation) & 6.49 & 8.57 \\
\hline$M_{3}$ (Border strip) & $\mathbf{0 . 0 6 3}$ & $\mathbf{0 . 3 1 9}$ \\
\hline SE(m) \pm & $\mathbf{N S}$ & $\mathbf{N S}$ \\
\hline CD at 5\% & & \\
\hline Mulching (MC) & 7.29 & 9.67 \\
\hline MS (Mulching with wheat straw) & 6.88 & 9.21 \\
\hline MG (Mulching with grasses) & 7.76 & 10.72 \\
\hline MP (Mulching with plastic sheet) & 4.70 & 4.78 \\
\hline MN (No mulch) & $\mathbf{0 . 0 8 9}$ & $\mathbf{0 . 3 8 4}$ \\
\hline SE(m) \pm & $\mathbf{0 . 2 5 8}$ & $\mathbf{1 . 1 1 4}$ \\
\hline CD at 5\% & & \\
\hline
\end{tabular}

\section{Number of pods per plant}

No irrigation is given to any treatment due to continuous rainfall. Hence, there are no differences among the methods of irrigation. Mulching with plastic sheet resulted in significantly higher number of pods per plant (7.76), and it was followed by wheat straw and grasses mulching.

\section{Length of pod (cm)}

The maximum length of pod was recorded under mulching with plastic sheet, followed by mulching with grasses, but it was at par with mulching with wheat straw.

Based on the experimentation it may be concluded that the result of method of irrigation is found to be non significant due to continuous rainfall. Hence, there are no differences among the methods of irrigation. Mulching with plastic sheet in okra var. VRO-6 proved the best mulch practice which produced superior growth and yield attributing characters.

\section{References}

Abdel-Hafeez, A.T. and Abu-Goukh, A.A. (1984). Use of plastic mulch on cucumber (Cucumis sativus) production under Sudan conditions. Sudan Agricultural Journal, 10: 19-27.

Aiyelaagbe, I. O. O. and Ogbonnaya, F. C. (1996). Growth, fruit production and seed yield of okra (Abelmoschus esculentus L) in response to irrigation and mulching. Research Bulletin National Horticultural Research Institute, Ibadan; 18: 13.

Batra, B.R., Inder, M., Arora, S.K. and Mohan, I. (2000). Effect of irrigation and nitrogen levels on dry matter production by okra (Abelmoschus esculentus L. Moench). Haryana Journal of Horticultural Science, 29(3\&4): 239241. 
FAO (2009). FAOSTAT, FAO Statistics Division 2009. Available at http://faostat.fao.org.

Gopalan, C., Rama-Sastri, B.V. and Balasubramanian, S.C. (1989). Nutritive value of Indian foods. National institute of Nutrition, ICMR, Hyderabad, India.

Ham, J.M.; Kluitenberg, G.J. and Lamont, W.J. (1993). Optical properties of plastic mulches affect the field temperature regime. Journal of the American Society for Horticultural Science, 118: 188-193.

Home, P.G., Kar, S. and Panda, R.K. (2000). Effect of irrigation scheduling on water and nitrogen balances in the crop root zone. Zeitschrift f'ur Bewasserung swirtschaft, 35(2): 223-235.

Hooda, R.S., J. Singh, Y.S. Malik and Batra, V.K. (1999). Influence of direct seeding, transplanting time and mulching on tomato yield. Vegetable Science, 26(2): 140- 142.

Jackson, M.L. (1967). Soil Chemical Analysis. Prentice Hall of india Pvt. Ltd. Delhi. Pp.-327-350

Manjunath, B.L., Mishra, P.K., Rao, J.V. and Reddy, G.S. (1994). Water requirement of vegetables in a dryland watershed. Indian Journal of Agricultural Sciences, 64(12): 845-846.

Mehta, A.P. and Prihar, S.S. (1973). Seedling emergence in soybean and cotton as affected by seedbed characteristics and surface mulches. Indian J. Agric. Sci. 43(1): 45-49.
Mehta, Y.R. (1959). Vegetable Growing in Uttar Pradesh Bureau of Agric inf. Lucknow. U.P

Olsen, S.R., Cole, C.V., Watanabe, F.S. and Dean, L.P. (1954). Estimation of available phosphorus in soils by extraction with sodium bicarbonate. USDA Circular, 937.

Singh, B.P. (1987). Effect of irrigation on the growth and yield of okra. Hort. Sci., 22: 879-880.

Singh, K. and Gangwar, R.P. (1972). Effect of mulching in the production of potato. $\mathrm{J}$. Haryana Hort. Sci., 1: 39-45.

Singh, K., Vashistha, R.N., Pandita, M.L. and Batra, B.R. (1976). Effect of mulching on growth, and yield of cucurbits under rain fed condition. J. Haryana Hort. Sci., 5:87-91.

Subbaih, B.V. and G.L. Asija (1956). A rapid procedure for the estimation of available nitrogen in soils. Curr. Sci. 5: 259-268.

Tarara, J.M. (2000). Microclimate modification with plastic mulch. Hort. Sci., 35: 169-180.

Walkley, A. and Black, I.A. (1934). Estimation of soil organic carbon by chromic acid titration method. Soil Science 37: 29-38.

Walter, B. 1988. Influence of bark mulch on water balance, soil water quality, mineralization and nitrification in skeletal Devonian Viney and soils. Hort. Abst. 59(9): 835.

\section{How to cite this article:}

Vinita Parte, Pratibha Dagore, Anjana Kujur and Urvashi Markam. 2020. Effect of Mulching and Methods of Irrigation on Okra (Hibiscus esculentus L. Moench). Int.J.Curr.Microbiol.App.Sci. 9(02): 759-765. doi: https://doi.org/10.20546/ijcmas.2020.902.093 